\title{
Electric Power Research Institute Environmental Control Technology Center Report to the Steering Committee
}

\section{Monthly Report December 1997}

Work Performed Under Contract No.: DE-FG22-94PC93256

\author{
For \\ U.S. Department of Energy \\ Office of Fossil Energy \\ Federal Energy Technology Center \\ P.O. Box 880 \\ Morgantown, West Virginia 26507-0880
}

By
EPRI ECTC
7725 Lake Road

Barker, New York 14012 


\section{Disclaimer}

This report was prepared as an account of work sponsored by an agency of the United States Government. Neither the United States Government nor any agency thereof, nor any of their employees, makes any warranty, express or implied, or assumes any legal liability or responsibility for the accuracy, completeness, or usefulness of any information, apparatus, product, or process disclosed, or represents that its use would not infringe privately owned rights. Reference herein to any specific commercial product, process, or service by trade

name, trademark, manufacturer, or otherwise does not necessarily constitute or imply its endorsement, recommendation, or favoring by the United States Government or any agency thereof. The views and opinions of authors expressed herein do not necessarily state or reflect those of the United States Government or any agency thereof. 
ELECTRIC POWER RESEARCH INSTITUTE

ENVIRONMENTAL CONTROL TECHNOLOGY CENTER

\title{
REPORT TO THE STEERING COMMITTEE
}

\author{
Monthly Technical Progress Report \\ US/DOE Patent Clearance is not Required \\ Prior to the Publication of this Document
}

December 1997

\author{
Prepared by: \\ EPRI/ECTC \\ Parsons \\ February 18, 1998 \\ DOE Grant \# DE-FG22-94PC93256 --46 \\ EPRI ECTC \\ 7725 Lake Road \\ Barker, New York 14012
}




\section{DISCLAIMER}

This report was prepared as an account of work sponsored by an agency of the United States Government. Neither the United States Government nor any agency thereof, nor any of their employees, makes any warranty, express or implied, or assumes any legal liability or responsibility for the accuracy, completeness, or usefulness of any information, apparatus, product, or process disclosed, or represents that its use would not infringe privately owned rights. Reference herein to any specific commercial product, process, or service by trade name, trademark, manufacturer, or otherwise does not necessarily constitute or imply its endorsement, recommendation, or favoring by the United States Government or any agency thereof. The views and opinions of authors expressed herein do not necessarily state or reflect those of the United States Government or any agency thereof.

\section{CAUTIONS TO USE OF THIS REPORT}

This report is a compilation of monthly progress reports by EPRI contractors (Radian International, Parsons Power) connected with the Environmental Control Technology Center (ECTC). This report is intended to provide timely information regarding the status of testing and research to the ECTC co-sponsoring organizations. All data, results, and remarks contained in this report should be considered preliminary based on the information available to date. Any speculation or conclusions discussed in this report are subject to change as additional information becomes available.

Neither EPRI, members of EPRI, Radian International, Parsons Power, or any person acting on behalf of any of them makes any warranty, express or implied, with respect to the use of any information, apparatus, method, or process disclosed in this report, or that any such use may not infringe privately owned rights. Neither EPRI, members of EPRI, Radian International, Parsons Power, or any person acting on behalf of any of them assumes any liabilities with respect to the use of, or for damages resulting from the use of any information, apparatus, method, or process disclosed in this report.

For further information on:

Facility Operations and Miscellaneous ECTC inquires; contact - Gary Andes (716) 795-3397

Wet FGD/Toxics Testing, Spray Drying/Dry FGD/Duct Injection technologies; contact - Richard Rhudy (650) 855-2421

Air Toxics/Carbon Injection for Mercury Control contact - Ramsay Chang (650) 855-2535 


\section{TABLE OF CONTENTS}

I. EXECUTIVE SUMMARY

II. FACILITY STATUS

- General

- EPRI/ADA Sorbent Sampling System

- December Outage Activities

- Financial Report

III. PILOT AND MINI-PILOT TEST ACTIVITY

- Testing Overview

- Summary of Operations

- Summary of Results

- Future Testing

IV. APPENDIX A Test Schedule(s) 


\section{EXECUTIVE SUMMARY}

\section{General Operations}

Operations and maintenance continued this month at the Electric Power Research Institute's (EPRI's) Environmental Control Technology Center (ECTC). Testing for the month involved the EPRI/ADA Technologies dry sorbent sampling unit and the testing of $\mathrm{Hg}$ catalysts/sorbents in this low-flow, temperature controlled system.

The 1.0 MW Cold-Side Selective Catalytic Reduction (SCR) unit, the 0.4 MW Mini Pilot Wet Scrubber, and the 4.0 MW Pilot Wet Scrubber remained idle this month in a cold-standby mode and were inspected regularly. These units remain available for testing as future work is identified.

\section{Pilot Testing Highlights}

A test program was initiated at the Center in December to investigate the performance of a new pilot-scale test unit/sorbent sampling system for power plant atmospheric mercury emissions, constructed by ADA Technologies for EPRI. The design of this unit allows for the simultaneous sampling of several new and innovative sorbent materials at a wide range of temperatures to determine their capture/oxidation efficiencies for vapor-phase mercury, and other flue gas compounds (SOx, NOx, etc.).

In this brief two-week test block, the objectives of the testing were to:

- Determine the best assembly and configuration for the unit to conduct testing under actual flue gas conditions;

- Streamline the inter-connections between components so that reliable, timely start-up can be achieved in other field settings;

- Correct any start-up problems with the unit so that is can be considered functional for testing at other sites; and,

- Collect Hg capture/removal data with the carbon sorbent samples supplied with the unit.

\section{Future Testing}

Due to a significant decrease in the 1998 cofunding allocations from EPRI and other ECTC cosponsors, the ECTC facility is currently in the process of closing-down its testing effort. While the ECTC has been a mainstay of EPRI's environmental control R\&D program for over 10 years, it is believed that the R\&D mission of the ECTC is now complete, and the facility should be transferred to the site owners, New York State Electric \& Gas (NYSEG), in exchange for a release from the close-down, restoration, and liability clauses in the ECTC site lease. During this close-down effort, NYSEG will provide the existing offices and business equipment to the ECTC to conduct EPRI business and properly prepare the site for closure and transfer. As such, this report will serve as the final monthly technical report for the ECTC testing effort in calendar year 1997. 


\section{FACILITY STATUS}

\section{General}

The NYSEG Kintigh Station provided flue gas to the Center $100 \%$ of the time during this performance period. As the Kintigh Station operated with a variety of coals, fluctuations in the Center's inlet $\mathrm{SO}_{2}$ concentrations were experienced.

Safety training for the month was conducted by the Operations Manager. Also, several tailgate safety sessions were held this month as the ECTC staff prepared the Facility for the 1997 Winter outage period. For this two-week outage (12/19/97$1 / 2 / 98$ ), it was required to denergize and isolate all of the major systems/components in the ECTC, drain and flush all tank and storage silo contents, and to place the Facility into a cold-standby mode until additional testing needs can be identified in 1998. As part of this Facility isolation effort, inspections of the entire Facility and its safety equipment (air-packs, fire extinguishers, etc.) were completed and recorded this month. All systems were found to be in good condition. By continuing to emphasize safe work habits at the Center, we have raised the total number of days without a lost time injury to 2036 as of 12/31/97.

The monthly safety meeting with the NYSEG Kintigh Station and the EPRI ECTC was held on December 11, 1997. The major topic of discussion was the effort(s) to isolate and secure the ECTC facility into a cold-standby mode for future testing.

\section{EPRI/ADA Sorbent Sampling System}

A test program was initiated at the Center in December to investigate the performance of a new pilot-scale test unit/sampling system constructed by ADA Technologies for EPRI. The design of this unit allows for the simultaneous sampling of several new and innovative sorbent materials at a wide range of temperatures to determine their capture/oxidation efficiencies for vapor-phase mercury, and other flue gas compounds (SOx, NOx, etc.).

In this brief two-week test block, the objectives of the testing were to:

- Determine the best assembly and configuration for the unit to conduct testing under actual flue gas conditions;

- Streamline the inter-connections between components so that reliable, timely start-up can be achieved in other field settings;

- Correct any start-up problems with the unit so that is can be considered functional for testing at other sites; and,

- Collect Hg capture/removal data with the carbon sorbent samples supplied with the unit. 
A listing of the various installation and start-up/check-out activities required for this sampling system is shown below. These activities were completed at the end of last month and at the beginning of the December test period prior to the sorbent characterization testing effort.

\section{EPRI/ADA System Installation and start-up/check-out activities}

- Review Installation drawings

- Provide Electrical service to unit (per instructions)

- Receive ADA unit and components/inventory

- Receive catalysts (carbon beds) for testing

- Hoist unit to SDA inlet elevation

- Position unit per flow schematic/elec. service locations

- Determine need for additional sampling locations beyond ESP outlet (TGR)

- Review installation notes/wiring schematics from ADA

- insulate tubing between manifold and ovens

- install TC in manifold box to control temp.

- wrap ss tubing between manifold and ovens with heater tape

- wire/connect blowers

- connect heated sample lines from manifold to sample train/CEMs

- connect $1 / 4$ " ss tubing from veturies to magnehelic gauges

- install TC (from temp control) in ss tubing bundle connecting ovens to manifold

- connect TC wire for hotline controller inputs

- connect $1 / 2$ " Teflon tubing from blowers to manifold

- Connect balance of unit components and power

- Connect CEMs to manifold box (inlet/outlet)

- Load Catalyst material for testing

- Order Hg sampling tubes/equipment (iodated carbon trap tubes)

\section{December Outage Activities}

With the reduction in testing backlog for 1998, a two-week outage period (12/19$1 / 2 / 98$ ) was conducted across the ECTC to isolate and secure the facility into a coldstandby mode for future testing as it is identified. A listing of the major activities required to isolate the ECTC is presented below.

- The facility gas flow was isolated at dampers $1,2,3$ and 27.

- The WDPF system, including all DPUs, remained energized along with the Allen Bradley system. All data collectors were shut down, including the VAX system. The VAX will be backed up periodically.

- The CEM system was shutdown and the sample probes were removed from the ductwork. The ESP and FF opacity monitors and the ESC P-5A were also removed.

- All flow transmitters, monitors and $\mathrm{pH}$ probes were drained and removed from ductwork.

- The Electric rooms, VSDs, Transformers, and electrical equipment remain 
energized. All rotating equipment will be inspected and rolled on a bi-weekly schedule.

- The ESP hopper heaters remain energized with $1 / 2$ of the insulator heaters. The inlet and outlet plenums were cleaned and ash was removed.

- The Air compressors remain energized.

- The service water and potable water systems were isolated and the headers were drained.

- The fire protection water system was isolated and drained.

- All remaining process and lab chemicals are being removed from the site.

- All Calibration gas cylinders were returned to their vendors by Dec. 19th.

- All acetylene, argon, oxygen bottles were returned to their vendor by Dec. 19th.

- All reagent storage, both tanks and storage silos, were emptied.

- The $\mathrm{SO}_{2}$ spiking system was emptied and purged. The leak detection system remains out of service awaiting the return of the power supply from the vendor. 


\section{Financial Report}

The Financial Report for the four Operations and Maintenance contract tasks are summarized below for the month of December 1997, the year to date, and the contract total.

$\underline{\text { Task Definitions: }}$

Task 100: Operations and Maintenance Labor

Task 200: Purchased Materials

Task 300: Engineering Support

Task 400: Training

Table i.

Monthly Operating Costs by Task

\begin{tabular}{|c|c|c|c|c|c|c|}
\hline & \multicolumn{2}{|c|}{ December } & \multicolumn{2}{|c|}{ Year to Date } & \multicolumn{2}{|c|}{ Contract Total } \\
\hline Task 100 & $\$$ & - & $\$$ & 291,236 & $\$$ & $14,761,049$ \\
\hline Task 200 & $\$$ & 13,107 & $\$$ & 118,709 & $\$$ & $8,629,855$ \\
\hline Task 300 & $\$$ & 1,186 & $\$$ & 103,017 & $\$$ & $1,297,605$ \\
\hline Task 400 & $\$$ & - & $\$$ & 228 & $\$$ & 53,463 \\
\hline DOE Grant & $\$$ & - & $\$$ & 132,616 & $\$$ & 248,792 \\
\hline TOTAL & $\$$ & 14,293 & $\$$ & 645,806 & $\$$ & $24,990,764$ \\
\hline
\end{tabular}


The attached graph illustrates the budgeted and actual expenses for ECTC O\&M activities through December 1997.

Figure i.

1997 Operation \& Maintenance Costs

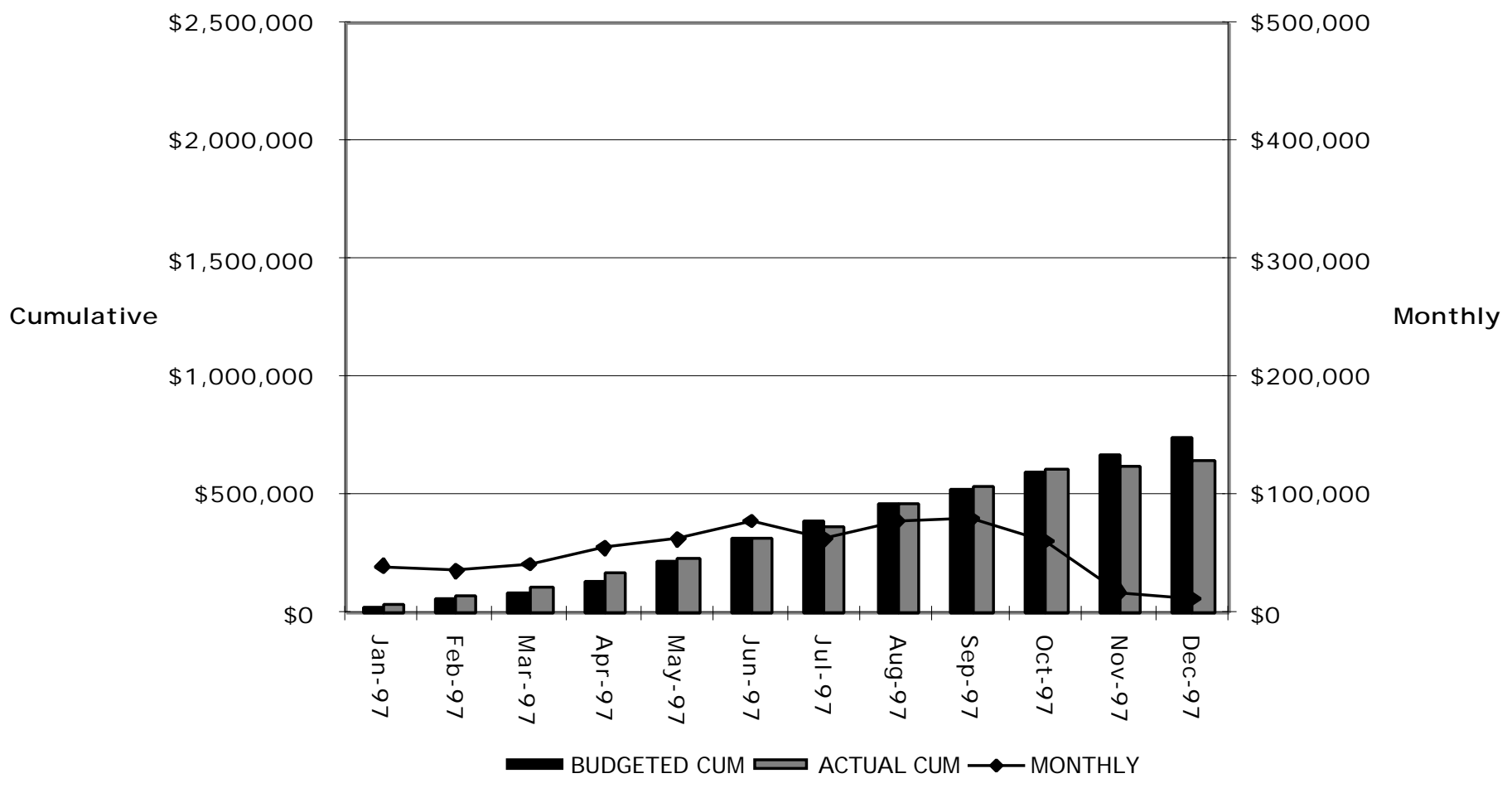




\section{PILOT AND MINI-PILOT TEST ACTIVITY}

\section{Testing Overview}

To complete the 1997 Air Toxics (mercury) testing effort at the ECTC, a test block with the new EPRI/ADA Technologies pilot-scale test unit was initiated this month. The design of this new sampling system/test unit is to allow the simultaneous sampling of several new and innovative sorbent materials at a wide range of temperatures to determine the capture/oxidation efficiencies of such sorbents for vapor-phase mercury, and other flue gas compounds (SOx, NOx, etc.). In this brief two-week test block, the objectives of the testing were to:

- Determine the best assembly and configuration for the unit to conduct testing under actual flue gas conditions;

- Streamline the inter-connections between components so that reliable, timely start-up can be achieved in other field settings;

- Correct any start-up problems with the unit so that is can be considered functional for testing at other sites; and,

- Collect Hg capture/removal data with the carbon sorbent samples supplied with the unit.

\section{$\underline{\text { Summary of Operations }}$}

The equivalent and actual availability for the EPRI/ADA test unit was 100\% during this period. There were no scheduled or forced outages during the testing this month.

The EPRI/ADA test block was initiated and completed this month with tests ADA-1; ADA-2; ADA-2R; ADA-3; ADA-3R; ADA-4; ADA 4R; ADA-5; ADA-6; and ADA-6R. After the unit was assembled and verified during a brief start-up/check-out period, the remaining objective for the test block was to conduct low-flow sampling across the test unit for total vapor-phase mercury in the ECTC flue gas downstream from the ECTC ESP.

For this testing, the ECTC flue gas path was configured so that the particulate and acid-gas rich dirty raw gas (DRG) from the facility inlet would flow through the Spray Dryer Absorber (SDA) for temperature control, and then through the ESP and the ECTC outlet ductwork. During the testing, a low-flow $(1-2 \mathrm{cfm})$ slipstream of flue gas was taken at the ESP outlet ductwork and directed to the EPRI/ADA test unit. A flow schematic for this test unit is shown in Figure 1. The operational parameters for the EPRI/ADA testing during this period included: gas flow of 4,000 scfm; inlet $\mathrm{SO}_{2}$ concentration as received from the Kintigh Station (approx. 1500 ppm); an ESP outlet particulate loading of 0.1-0.2 lb./MMBTU; and an inlet flue gas temperature of $300^{\circ} \mathrm{F}$. 


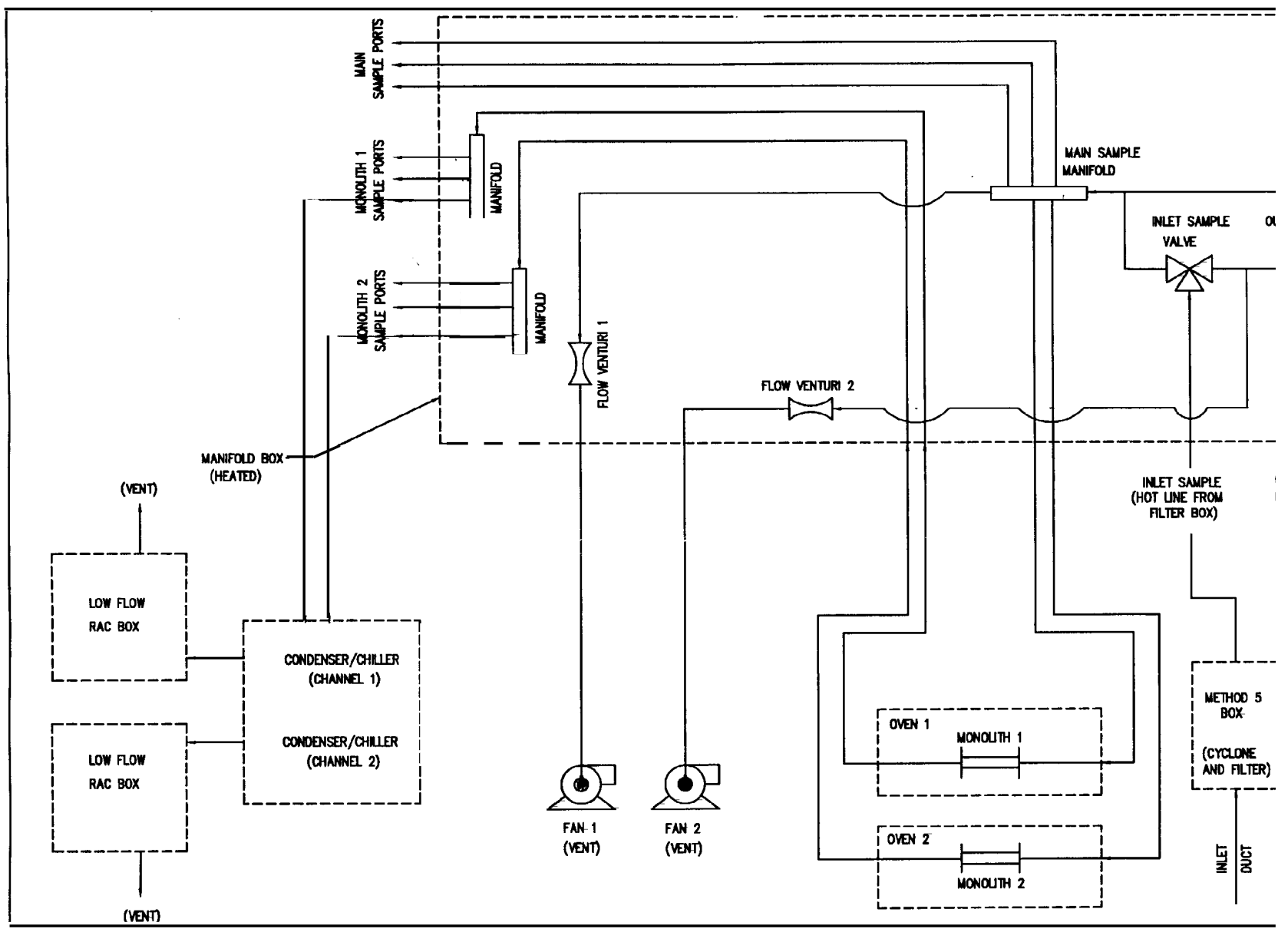

Figure 1. Process Flow Schematic for EPRI/ADA Sorbent Sampling Uni 
Before entering the test unit, the flue gas was analyzed by the ECTC CEM system for inlet concentrations of $\mathrm{SO}_{2}, \mathrm{O}_{2}$, and particulate matter. This flue gas slipstream was also drawn through standard gas sampling filter holders/cyclones to remove any remaining particulate in the gas stream. Once filtered, the flue gas was sampled to determine the inlet vapor-phase mercury concentrations. During this sampling, the filtered flue gas flow continued to the test unit and was directed to a manifold box where the gas stream was further sampled, split, and directed to two separate catalyst/sorbent support holders in individual oven chambers. As the gas stream flowed across each sorbent, the exit flow was directed back to the manifold box, drawn through a condenser/chiller to remove any condensed acids from the flue gas, and then sampled to determine the outlet gas concentrations of total vaporphase mercury.

To collect all of the total vapor-phase mercury samples taken upstream of and across the test unit, iodated carbon tubes were ordered from Frontier Geosciences and were used with EPRI low-flow sample pumps and meters supplied by Frontier Geosciences. A listing of the various tests and conditions during this test block is shown in Table 1. 
Table 1. December 1997 EPRI/ADA Test Block Operating Summary

\begin{tabular}{|c|c|c|c|}
\hline Date & Test ID & Number of Samples & Test Description \\
\hline $\begin{array}{l}12 / 5 \\
\text { Fri. }\end{array}$ & 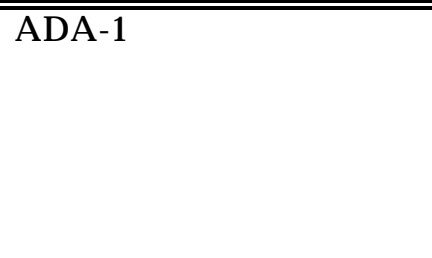 & $\begin{array}{l}8 \text { samples } \\
2 \text { inlet and one at each } \\
\text { outlet (4) and dup. }\end{array}$ & $\begin{array}{l}\text { Load carbon monoliths } \\
\text { with 1" dia., } 23 \text { mm long } \\
\text { samples of P-5 and P-200N } \\
\text { carbon. They will remain in } \\
\text { place throughout testing (no } \\
\text { changeout). }\end{array}$ \\
\hline $\begin{array}{l}12 / 8 \\
\text { Mon. }\end{array}$ & $\begin{array}{l}\text { ADA-1 } \\
\text { ESP inlet conditions: "E" } \\
\text { field, 4,000 scfm and } 300^{\circ} \mathrm{F} \\
\text { inlet temp. }\end{array}$ & none & $\begin{array}{l}\text { Bring ESP on gas flow. } \\
\text { Calibrate CEMs and allow } \\
\text { facility to warm to test } \\
\text { conditions }\end{array}$ \\
\hline $\begin{array}{l}12 / 9 \\
\text { Tues. }\end{array}$ & $\begin{array}{l}\text { ADA-2 and ADA-2R } \\
\text { ADA-3 and ADA-3R } \\
\text { ESP inlet conditions: "E" } \\
\text { field, } 4,000 \text { scfm and } 300^{\circ} \mathrm{F} \\
\text { inlet temp. }\end{array}$ & $\begin{array}{l}12 \text { samples: } \\
3 \text { samples and dup. in the } \\
\text { morning, } 3 \text { samples and } \\
\text { dup. in the afternoon. } \\
\text { Additional carbon sample } \\
\text { tubes to arrive from } \\
\text { Frontier Geosciences }\end{array}$ & $\begin{array}{l}\text { Energize ADA system and } \\
\text { achieve proper temperatures } \\
\text { across probe, filter, ovens, etc. } \\
\text { Calibrate CEMs. } \\
\text { - Once at process temp., } \\
\text { initiate blower } 1 \text { and adjust } \\
\Delta \text { p for proper flow. } \\
\text {-Insert probe into TGR duct } \\
\text { and start first set of morning } \\
\text { samples as soon as unit is } \\
\text { stable (one inlet and one at } \\
\text { each outlet - } 3 \text { total). Record } \\
\text { sample volumes. } \\
\text {-Conduct duplicate sample as } \\
\text { soon as first set is finished } \\
\text { (one inlet and one at each } \\
\text { outlet - } 3 \text { total) Record } \\
\text { sample volumes. } \\
\text { - Conduct first set of afternoon } \\
\text { samples after lunch (one inlet } \\
\text { and one at each outlet - } 3 \\
\text { total) Record sample } \\
\text { volumes. } \\
\text {-Conduct duplicate sample as } \\
\text { soon as first set is finished } \\
\text { (one inlet and one at each } \\
\text { outlet - } 3 \text { total) Record sample } \\
\text { volumes. } \\
\text {-Allow sampling unit to } \\
\text { operate overnight and record } \\
\text { data }\end{array}$ \\
\hline
\end{tabular}


Table 1. December 1997 EPRI/ADA Test Block Operating Summary (cont.)

\begin{tabular}{|c|c|c|c|}
\hline Date & Test ID & Number of Samples & Test Description \\
\hline $\begin{array}{l}12 / 10 \\
\text { Wed. }\end{array}$ & $\begin{array}{l}\text { ADA- } 4 \text { and ADA-4R } \\
\text { ESP inlet conditions: “E” } \\
\text { field, } 4,000 \mathrm{scfm} \text { and } 300^{\circ} \mathrm{F} \\
\text { inlet temp. }\end{array}$ & $\begin{array}{l}6 \text { samples: } \\
1 \text { set (one inlet and one at } \\
\text { each outlet) and dup. } \\
\text { To be taken either late } \\
\text { morning or early afternoon. }\end{array}$ & $\begin{array}{l}\text {-Conduct one set of samples } \\
\text { (one inlet and one at each } \\
\text { outlet - } 3 \text { total) Record } \\
\text { sample volumes. } \\
\text {-Conduct duplicate sample as } \\
\text { soon as first set is finished } \\
\text { (one inlet and one at each } \\
\text { outlet - } 3 \text { total) Record sample } \\
\text { volumes. } \\
\text {-Allow sampling unit to } \\
\text { operate overnight and record } \\
\text { data }\end{array}$ \\
\hline $\begin{array}{l}\text { 12/11 } \\
\text { Thurs. }\end{array}$ & $\begin{array}{l}\text { ADA-5 } \\
\text { ESP inlet conditions: “E” } \\
\text { field, } 4,000 \mathrm{scfm} \text { and } 300^{\circ} \mathrm{F} \\
\text { inlet temp. }\end{array}$ & No sampling & $\begin{array}{l}\text {-Providing operating time } \\
\text { with carbon samples. } \\
\text {-Allow sampling unit to } \\
\text { operate during the day and } \\
\text { overnight and record data }\end{array}$ \\
\hline $12 / 12$ & $\begin{array}{l}\text { ADA-6 and ADA-6R } \\
\text { ESP inlet conditions: “E” } \\
\text { field, } 4,000 \mathrm{scfm} \text { and } 300^{\circ} \mathrm{F} \\
\text { inlet temp. }\end{array}$ & $\begin{array}{l}6 \text { samples: } \\
1 \text { set (one inlet and one at } \\
\text { each outlet) and dup. } \\
\text { To be taken late morning } \\
\text { before shut-down }\end{array}$ & $\begin{array}{l}\text {-Conduct one set of samples } \\
\text { (one inlet and one at each } \\
\text { outlet - } 3 \text { total) Record } \\
\text { sample volumes. } \\
\text {-Conduct duplicate sample as } \\
\text { soon as first set is finished } \\
\text { (one inlet and one at each } \\
\text { outlet -3 total) Record sample } \\
\text { volumes. } \\
\text {-Complete sampling by noon. } \\
\text {-Purge unit and ESP on air. } \\
\text {-ECTC off-line. }\end{array}$ \\
\hline $\begin{array}{l}\text { 12/15-12/19 } \\
\text { Mon.-Fri. }\end{array}$ & $\begin{array}{l}\text { ECTC outage } \\
\text { No gas flow }\end{array}$ & & $\begin{array}{l}\text {-Begin ECTC outage } \\
\text { activities to secure facility in } \\
\text { cold-standby. } \\
\text {-Begin disassembly of ADA } \\
\text { sampling system, return } \\
\text { components to shop and } \\
\text { prepare to ship back to ADA } \\
\text { for modification and testing. }\end{array}$ \\
\hline
\end{tabular}




\section{$\underline{\text { Summary of Results }}$}

All of the objectives for this brief study were achieved during the December test period. Although the EPRI/ADA test unit had never been assembled and pre-tested before arriving at the ECTC, the Center's staff were able to easily configure the unit for testing with the installation information and instructions received from ADA Technologies.

As the actual window for testing was short this month, it was critical to complete the majority of the installation and check-out/start-up activities at the end of last month (installation activities listed previously). Much of this work involved the completion of inter-connections and electrical and instrumentation/controls (I\&C) service as these parts were received from ADA with the other major components. While there were only a few minor problems encountered during the startup/check-out phase of the program, the most inconvenient piece of the system was the monolith holder(s). Though the holders that we received for the unit were not built as originally designed, we believe that a better design for these holders exits which will help in the installation and changeout of new monoliths for each sorbent study.

To characterize the performance of the sampling system and evaluate the sorbents for $\mathrm{Hg}$ capture/removal, the filtered flue gas flow from the ECTC sample probes was directed through Teflon hotlines to the test unit and its electropolished stainless steel plumbing and components. Once at the inlet to the sampling system, the flue gas flow passed through a manifold box and was further sampled, split, and directed to the two separate catalyst/sorbent monolith holders in individual oven chambers. With $\mathrm{Hg}$ sampling upstream of the test unit, as well as upstream and downstream of each sorbent monolith, the performance of the system and the sorbent was determined. The results and analytical data from this sampling effort for total vapor-phase mercury is presented in Table 2 below. 
Table 2. Summary Analytical Data from Dry Sorbent Test Unit Sampling

\author{
EPRI /ADA \\ Low Flow Dry Sorbent Test Unit - Sample Data \\ 11/24/97 - 12/12/97
}

\begin{tabular}{|c|c|c|c|c|c|c|c|}
\hline Date & Sample ID & Time & Location & $\underset{\text { (L) }}{\text { Sample Volume }}$ & $\underset{\left(\mu \mathrm{g} / \mathrm{m}^{3}\right)}{\mathbf{H g}}$ & $\underset{(\%)}{\text { Hg Removal }}$ & Note \\
\hline 5-Dec-97 & ADA - 1 & $9: 00$ & Hot Box Outlet & 17.2 & 4.51 & & Baseline - \\
\hline 5-Dec-97 & $\mathrm{ADA}-2$ & 9:08 & Monolith \#1 & 18.2 & 3.43 & & \\
\hline 5-Dec-97 & ADA - 3 & 9:08 & Hot Box Outlet & 19.5 & 4.41 & & Blank \\
\hline 5-Dec-97 & $\mathrm{ADA}-4$ & $9: 48$ & Manifold Inlet & 17.0 & 3.39 & & Mono \#1 \& 2 \\
\hline 5-Dec-97 & ADA - 5 & $10: 15$ & Manifold Inlet & 17.2 & 4.06 & & \\
\hline 5-Dec-97 & ADA - 6 & $10: 15$ & Monolith \#1 & 17.0 & 4.39 & & \\
\hline 5-Dec-97 & $\mathrm{ADA}-7$ & $10: 57$ & Manifold Inlet & 17.1 & 4.31 & & \\
\hline 5-Dec-97 & ADA - 8 & $10: 57$ & Monolith \#2 & 17.0 & 3.83 & & \\
\hline 6-Dec-97 & ADA - 9 & 9:01 & Manifold Inlet & 17.0 & 1.25 & - & \\
\hline 6-Dec-97 & ADA - 10 & $9: 27$ & Monolith \#1 & 17.1 & 1.12 & 10.40 & P200 Carbon \\
\hline 6-Dec-97 & ADA - 11 & $9: 42$ & Monolith \#2 & 17.1 & 0.40 & 68.00 & P5 Carbon \\
\hline 6-Dec-97 & ADA - 12 & $10: 10$ & Manifold Inlet & 17.0 & 2.51 & - & dup \\
\hline 6-Dec-97 & ADA - 13 & $10: 23$ & Monolith \#1 & 17.0 & 1.71 & 31.87 & dup \\
\hline 6-Dec-97 & ADA - 14 & $10: 50$ & Monolith \#2 & 17.0 & 0.53 & 78.88 & dup \\
\hline 6-Dec-97 & ADA - 15 & $12: 53$ & Manifold Inlet & 17.0 & 4.20 & - & \\
\hline 6-Dec-97 & ADA - 16 & $12: 54$ & Monolith \#1 & 17.2 & 2.26 & 46.19 & P200 Carbon \\
\hline 6-Dec-97 & ADA - 17 & $13: 34$ & Monolith \#2 & 17.4 & 0.66 & 84.29 & P5 Carbon \\
\hline 6-Dec-97 & ADA - 18 & $13: 33$ & Manifold Inlet & 17.0 & 4.14 & - & dup \\
\hline 6-Dec-97 & ADA - 19 & $14: 15$ & Monolith \#1 & 17.0 & 2.26 & 45.41 & dup \\
\hline 6-Dec-97 & ADA - 20 & $14: 16$ & Monolith \#2 & 17.0 & 0.59 & 85.75 & dup \\
\hline 10-Dec-97 & ADA - 21 & $10: 32$ & Manifold Inlet & 17.0 & 6.70 & - & \\
\hline 10-Dec-97 & $\mathrm{ADA}-22$ & $10: 33$ & Monolith \#1 & 17.0 & 3.89 & 41.94 & P200 Carbon \\
\hline 10-Dec-97 & $\mathrm{ADA}-23$ & $11: 19$ & Monolith \#2 & 17.0 & 2.02 & 69.85 & P5 Carbon \\
\hline 10-Dec-97 & $\mathrm{ADA}-24$ & $11: 18$ & Manifold Inlet & 17.0 & 6.00 & - & dup \\
\hline 10-Dec-97 & $\mathrm{ADA}-25$ & $11: 58$ & Monolith \#1 & 17.0 & 3.38 & 43.67 & dup \\
\hline 10-Dec-97 & ADA - 26 & $12: 00$ & Monolith \#2 & 17.0 & 1.90 & 68.33 & dup \\
\hline 12-Dec-97 & ADA - 27 & $7: 37$ & Manifold Inlet & 17.0 & 4.81 & - & \\
\hline 12-Dec-97 & ADA - 28 & $7: 38$ & Monolith \#1 & 17.0 & 3.73 & 22.45 & P200 Carbon \\
\hline 12-Dec-97 & ADA - 29 & $8: 22$ & Monolith \#2 & 18.5 & 3.25 & 32.43 & P5 Carbon \\
\hline 12-Dec-97 & ADA - 30 & $8: 23$ & Manifold Inlet & 19.0 & 5.42 & - & dup \\
\hline 12-Dec-97 & ADA - 31 & $9: 12$ & Monolith \#1 & 17.0 & 3.61 & 33.39 & dup \\
\hline 12-Dec-97 & ADA - 32 & $9: 13$ & Monolith \#2 & 17.0 & 2.98 & 45.02 & dup \\
\hline
\end{tabular}


In reviewing the analytical data from the sampling effort, the data shows that there were no problems in directing the flue gas from the ECTC ductwork to the test unit (without removing $\mathrm{Hg}$ or changing its speciation). By comparing the baseline (no sorbent) data for total vapor-phase mercury concentration at the filter box (hot box) outlet, the manifold inlet, and the manifold outlet, each sample value on average is within the sample analysis QC range of its duplicate sample (+/- $10 \%)$.

As the baseline testing was completed, a series of twenty-four (24) samples were collected at the manifold inlet and at each of the monolith holder outlets. For this testing, two (2) carbon-based sorbent monoliths were supplied by Mega Carbon, Pilot-200N and Pilot-5, and were tested for their performance in the removal of vapor-phase mercury from the flue gas. Based on the results from these sampling tests, the average mercury removal efficiency for the Pilot-200 sorbent was $36.58 \%$ after the first 6 sample periods, and $34.42 \%$ after all 8 sample periods. In comparison, the average mercury removal efficiency for the Pilot-5 sorbent was $75.85 \%$ after the first 6 sample periods, and $66.57 \%$ after all 8 sample periods. From this evaluation, the Pilot-5 sorbent removed roughly twice as much of the total vapor-phase mercury as the Pilot- $200 \mathrm{~N}$ sorbent. This agrees with the previous data supplied for these materials, shown in Tables 3 and 4 below.

Table 3. Properties of Carbon-based Sorbent Samples (Pilot-5 and P-200N)

\begin{tabular}{|c|c|c|c|c|}
\hline Sorbent name & Material type & $\begin{array}{c}\text { BET Surface area } \\
\left(\mathrm{m}^{2} / \mathrm{g}\right)\end{array}$ & $\begin{array}{c}\mathrm{Hg}^{0} \text { capacity } \\
(\mu \mathrm{g} / \mathrm{g})\end{array}$ & $\begin{array}{c}\mathrm{HgCl}_{2} \text { capacity } \\
(\mu \mathrm{g} / \mathrm{g})\end{array}$ \\
\hline P-200N & coal-based & $\overline{477}$ & 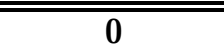 & 190 \\
\hline$P-5$ & coal-based & 690 & 1646 & 560 \\
\hline
\end{tabular}


Table 4. Previous bench-scale performance results for EPRI/ADA unit sorbents

Bench-Scale Testing

Fixed-Bed Adsorption of Mercury

\begin{tabular}{|c|c|c|c|c|c|c|c|}
\hline & & & $0 \% \mathrm{Br}$ & kthrough & $100 \%$ & eakthrough & \\
\hline Sample & Date & $\begin{array}{l}\text { Inlet [Hg] } \\
\text { (ug/Nm3) }\end{array}$ & $\begin{array}{l}\text { Time } \\
\text { (min) }\end{array}$ & $\begin{array}{c}\text { capacity } \\
\text { ug/g carbon }\end{array}$ & $\begin{array}{l}\text { Time } \\
\text { (min) }\end{array}$ & $\begin{array}{c}\text { capacity } \\
\text { ug/g carbon }\end{array}$ & $\begin{array}{l}\text { capacity } \\
\mathrm{ng} / \mathrm{m} 2^{\star *}\end{array}$ \\
\hline $\mathrm{Hg}(0)$ Testin & & & & & & & \\
\hline HgCl2 Testir & & & & & & & \\
\hline Pilot-5 & 14-Oct & 43 & 323 & 598 & 358 & 620 & 891.7 \\
\hline Pilot-5 & $25-O c t$ & 53 & 351 & 734 & 483 & 874 & 1257 \\
\hline FGD & 17-Oct & 47 & 406 & 844 & 532 & 969 & 1927 \\
\hline FGD & 20-Oct & 55 & 387 & 945 & 540 & 1125 & 2237 \\
\hline FGD & 24-Oct & 64 & 377 & 980 & 576 & 1282 & 2550 \\
\hline Pilot-5N2 & 15-Oct & 61 & 0 & 0 & 87 & 105 & * \\
\hline Pilot-5NN & 15-Oct & 61 & 70 & 147 & 107 & 175 & * \\
\hline Pilot-5N1 & 15-Oct & 54 & 198 & 439 & 246 & 484 & * \\
\hline Pilot-5TPD & 16-Oct & 49 & 159 & 279 & 229 & 350 & * \\
\hline Pilot-5TPD & 19-Oct & 51 & 235 & 496 & 278 & 533 & * \\
\hline Pilot-5TPD & 20-Oct & 54 & 171 & 355 & 203 & 376 & * \\
\hline ACL-25 & 28-Oct & 48 & 416 & 884 & 876 & 1486 & 2804 \\
\hline ACL-28 & 29-Oct & 47 & 1129 & 2395 & 1401 & 2785 & 6162 \\
\hline IPAC-5 & 30-Oct & 48 & 1311 & 2755 & 1462 & 3069 & 4560 \\
\hline $97.1226 \mathrm{cal}$ & 1-Nov & 50 & 246 & 530 & 309 & 582 & 831.4 \\
\hline IAC-20 & 2-Nov & 52 & 222 & 444 & 256 & 470 & 590.5 \\
\hline
\end{tabular}

* - do not have BET surface area data

** - calculation based on BET surface area 


\section{Future Testing}

Due to a significant decrease in the 1998 cofunding allocations from EPRI and other ECTC cosponsors, the ECTC facility is currently in the process of closing-down its testing effort. While the ECTC has been a mainstay of EPRI's environmental control $R \& D$ program for over the past 10 years, it is believed that the R\&D mission of the ECTC is now complete, and the facility should be transferred to the site owners, New York State Electric \& Gas (NYSEG), in exchange for a release from the close-down, restoration, and liability clauses in the ECTC site lease. During this close-down effort, NYSEG will provide the existing offices and business equipment to the ECTC to conduct EPRI business and properly prepare the site for closure and transfer. As such, this report will serve as the final monthly technical report for the ECTC testing effort in calendar year 1997. 
APPENDIX A

TEST SCHEDULE(S) 


\begin{tabular}{|c|c|c|c|c|c|c|c|c|c|c|c|c|c|}
\hline & \multicolumn{13}{|c|}{1996} \\
\hline & JAN & FEB & MAR & APR & MAY & JUN & JUL & AUG & SEP & OCT & NOV & & \\
\hline $\begin{array}{l}\text { 4.0 MW Pilot } \\
\text { FGD Unit }\end{array}$ & \multicolumn{2}{|c|}{$\begin{array}{l}\text { EPRI Wet FGD } \\
\text { Toxics Testing }\end{array}$} & \multicolumn{3}{|c|}{$\begin{array}{l}\text { DOE/PRDA Phase I - } \\
\text { Mercury and HAPs } \\
\text { Control with Wet FGD }\end{array}$} & $\begin{array}{l}\text { EPRI } \\
\text { Toxic: }\end{array}$ & et FGD & \multicolumn{2}{|c|}{$\begin{array}{l}\text { Third party } \\
\text { Testing - } \\
\text { Rotorfilter } \\
\text { Technology } \\
\end{array}$} & \begin{tabular}{|c|} 
EPRI Toxics \\
Removal \\
Testing \\
\end{tabular} & \multicolumn{2}{|c|}{$\begin{array}{l}\text { EPRI } \\
\text { SOx/NOx } \\
\text { Process } \\
\text { Testing } \\
\end{array}$} & \begin{tabular}{|l|} 
ECTC \\
Fall \\
Outage \\
\end{tabular} \\
\hline $\begin{array}{l}\text { 0.4 MW Mini- } \\
\text { Pilot FGD Unit }\end{array}$ & \multicolumn{2}{|c|}{$\begin{array}{l}\text { Remove Mini-Pilot } \\
\text { Scrubber and install } \\
\text { CHX for testing }\end{array}$} & \multicolumn{11}{|c|}{ DOE/PRDA Phase I - Multiple Pollutant Removal Using the Condensing Heat Exchanger (CHX) } \\
\hline
\end{tabular}

\begin{tabular}{|c|c|c|c|c|c|c|c|c|c|c|c|c|c|}
\hline & \multicolumn{13}{|c|}{1997} \\
\hline & JAN & FEB & MAR & APR & MAY & JUN & JUL & AUG & SEP & OCT & NOV & DEC & \\
\hline $\begin{array}{l}\text { 4.0 MW Pilot } \\
\text { FGD Unit }\end{array}$ & \multicolumn{4}{|c|}{$\begin{array}{l}\text { DOE/PRDA Phase I - Clear Liquor Scrubbing } \\
\text { (CLS) with Anhydrite Production }\end{array}$} & \begin{tabular}{|c|} 
NYSEd \\
Spring \\
Outage
\end{tabular} & $\begin{array}{l}\text { CLS Anhydrite } \\
\text { extension } \\
\text { testing }\end{array}$ & & \multicolumn{4}{|c|}{$\begin{array}{l}\text { Dry Sorbent Injection for } \mathrm{Hg} \\
\text { Removal and ESP } \\
\text { performance studies }\end{array}$} & $\begin{array}{l}\text { EPRI/ } \\
\text { ADA Hg } \\
\text { test unit }\end{array}$ & $\begin{array}{l}\text { ECTC } \\
\text { Fall } \\
\text { Outage }\end{array}$ \\
\hline $\begin{array}{l}\text { ECTC Bench- } \\
\text { scale FGD Unit }\end{array}$ & \multicolumn{12}{|c|}{ Unit Available for EPRI/TC/CoSponsor/Third-Party Testing } & \begin{tabular}{|l|} 
ECTC \\
Fall \\
Outage
\end{tabular} \\
\hline $\begin{array}{l}\text { 0.4 MW Mini- } \\
\text { Pilot FGD Unit }\end{array}$ & \multicolumn{3}{|c|}{$\begin{array}{c}\text { DOE/PRDA Phase I- } \\
\text { Condensing Heat Exchanger } \\
\text { (CHX) Testing } \\
\end{array}$} & \multicolumn{2}{|c|}{$\begin{array}{l}\text { Reconfigure } \\
\text { Mini-Pilot } \\
\text { Scrubber } \\
\end{array}$} & $\begin{array}{c}\begin{array}{c}\text { CLS Anhydrite } \\
\text { extension } \\
\text { testing }\end{array} \\
\end{array}$ & & \multicolumn{5}{|c|}{$\begin{array}{c}\text { Unit Available for } \\
\text { EPRI/TC/CoSponsor/Third-Party Testing }\end{array}$} & \begin{tabular}{|l|} 
ECTC \\
Fall \\
Outage \\
\end{tabular} \\
\hline
\end{tabular}

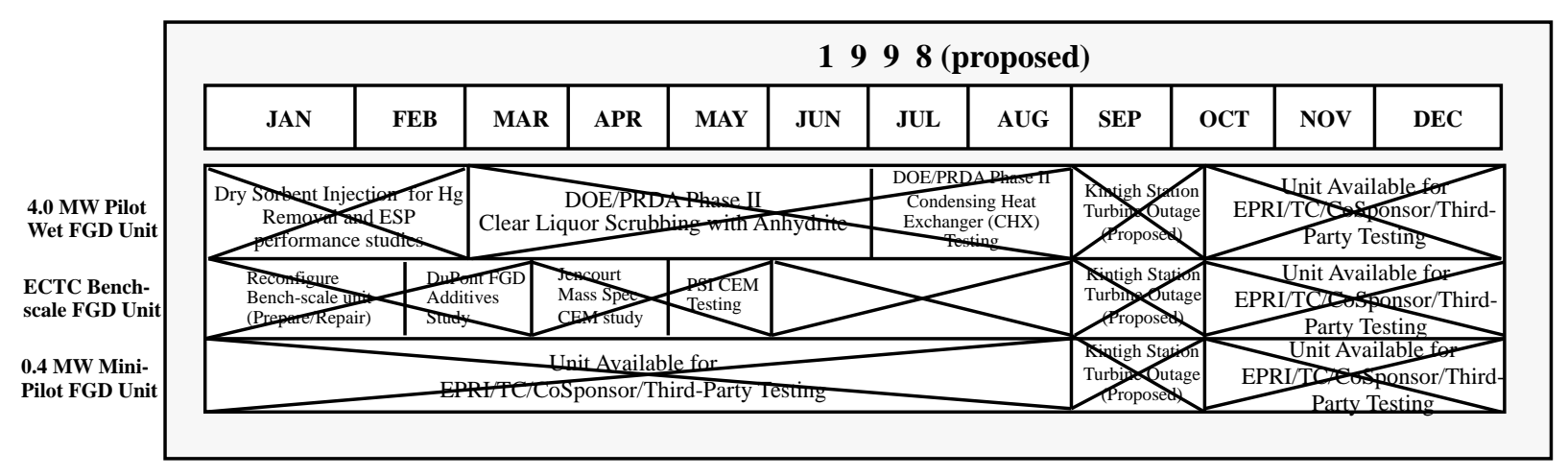

ECTC Test Schedule ('96 - '98) 


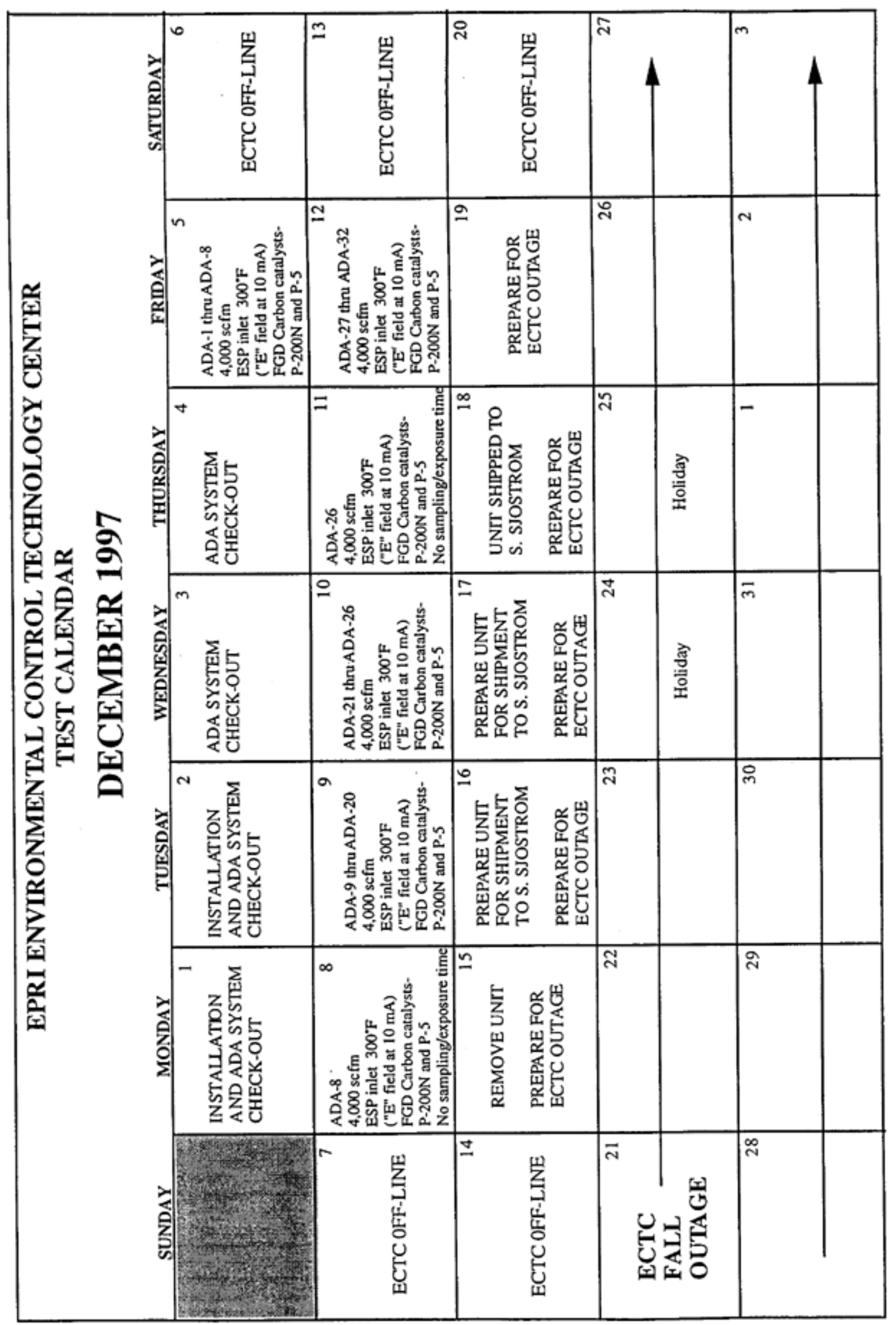




\section{ECTC COSPONSORS DISTRIBUTION}

Mr. John E. Smigelski

New York State Electric \& Gas

Corporate Drive, Kirkwood Ind. Park

P. O. Box 5224

Binghamton, NY 13902-5224

Ph: (607) 762-8688

Fax: (607) 762-8457

Dr. Gerald Janik

New York State Electric \& Gas

Corporate Drive, Kirkwood Ind. Park

P. O. Box 5224

Binghamton, NY 13902-5224

Ph: (607) 762-4318

Fax: (607) 762-8457
Ms. JoAnn C. Zysk

U.S. Department of Energy

Federal Energy Technology Center

P. O. Box 10940, MS 900-33

Pittsburgh, PA 15236

Ph: (412) 892-6200

Fax: (412) 892-6216

Mr. Michio Kurihara

Electric Power Development Co., Ltd.

15-1, Ginza 6-Chome, Chuo-ku

Tokyo, 104 JAPAN

Ph: (81) 3-3546-9404

Fax: (81) 3-3546-9482

Ms. Debra DiMeo

Empire State Electric Energy Res. Corp.

1515 Broadway

New York, NY 10036

Ph. (212) 302-1212

Fax: (212) 302-1377

\section{EPRI DISTRIBUTION}
G. Andes
T. Armor
M. Miller
G. Offen
R. Rhudy W. Chow
R. Glover 